\title{
Motivasi Berpuasa Ramadhan dan Moralitas Remaja
}

\author{
Elly Marlina \\ UIN Sunan Gunung Djati Bandung \\ E_mail: ellymarlina_usman@yahoo.co.id
}

\begin{abstract}
This study aimed to determine the relationship between motivation of Ramadan fasting and morality in 120 students of the eighth grade of SMP Muhammadiyah 3 Bandung. The results showed that there is a positive and significant relationship between motivational variables of Ramadan fasting with the teens morality so it can be said that the higher motivation of Ramadan fasting, the higher the adolescent morality, and conversely, the lower the motivation of Ramadan fasting, the lower the their morality. Effective contribution given Ramadan fasting motivation variable related to their morality is around $29.8 \%$, while the remaining $70.2 \%$ were contributed by other factors that influence their morality are the home, school neighborhood, peers, religious terms and leisure activities.
\end{abstract}

\section{Kata kunci:}

Motivasi Berpuasa Ramadhan, Moralitas Remaja.

\section{A. Pendahuluan}

Pemahaman dan cara remaja memberikan keputusan merupakan cara yang baik mengenai moralitas remaja. Sesuatu yang dianggap remaja adalah benar atau salah merupakan gambaran kepada remaja untuk dapat memahami dunianya. Hal ini dikemukakan oleh Kohlberg (Duksa dan Whelan, 1984:57) yang mengungkapkan bahwa perkembangan moral anak terkait 
dengan perkembangan cara berpikir anak (kognitif). Artinya, semakin tinggi tingkat perkembangan berpikir anak, semakin besar pula potensi anak mencapai tingkat perkembangan moral yang lebih baik.

Proses menuju kematangan berpikir moralistis memerlukan waktu dan dasar pijakan moral yang lebih tepat. Hal tersebut menuntut kesabaran orang tua untuk membimbing anaknya dari tahap demi tahap. Peran orang tua sangatlah penting dalam perkembangan moralitas anaknya.

Seorang remaja harus mampu membina moral yang ada dalam dirinya melalui pengalaman yang dimilikinya dari masa kanak-kanak sampai dengan mencapai kematangan baik dalam segi jasmani, rohani, sosial dan ekonomi. Remaja akan menghadapi situasi dan keadaan yang belum pernah dihadapi sebelumnya. Remaja dituntut untuk mengadakan penilaian, merencanakan dan membuat keputusan yang sesuai dengan kehendaknya dan didasarkan pada prinsip moral.

Remaja yang berada dalam masa transisi membuat remaja dihadapkan pada berbagai kontradiksi. Masa remaja merupakan masa peralihan dari masa kanak-kanak kemasa dewasa yang lebih matang dan mampu berdiri sendiri, sehingga remaja selalu memikirkan nilai dan standar moral yang muncul dari agama dan lingkungan sosial (Mussen, 1989: 542).

Moral adalah istilah yang digunakan untuk menentukan batas-batas suatu sifat, perangai, kehendak, pendapat atau perbuatan yang layak dikatakan baik, benar, salah, atau buruk. Penilaian salah dan benar dipandang dari sudut hukum yang di dalam agama Islam tidak dapat diceraipisahkan, oleh karena itu untuk mengukur tingkah laku manusia, baik atau buruk, dapat dilihat apakah perbuatan itu sesuai dengan adat istiadat yang umum diterima (Ali, 2002: 354).

Agama mempunyai peranan penting dalam pembinaan moral karena nilai-nilai moral yang datang dari agama bersifat 
tetap dan universal. Apalagi ketika seseorang dihadapkan pada suatu masalah maka akan tetap memegang teguh keyakinan yang telah tertanam dalam hati nuraninya di manamun berada dan dalam kondisi apapun (Daradjat, 1991: 83).

An-Nahlawi (dalam Setiono, 1993) mengungkapkan bahwa remaja yang memperoleh pendidikan agama secara formal maupun informal, dalam berperilaku selalu memperhatikan dan mempertimbangkan dosa dan tidaknya, berani menyatakan bahwa yang benar itu benar dan yang salah itu salah sesuai dengan ajaran agamanya.

Selain mendapatkan pendidikan agama, dalam diri remaja juga harus ditanamkan moral agama yang merupakan usaha untuk memberikan kepada remaja suatu pedoman dan aturanaturan dalam kehidupan yang berdasarkan nilai-nilai agama agar remaja dapat mematuhi dan mengamalkannya dalam berinteraksi dengan lingkungan juga dapat digunakan sebagai bekal kehidupan di akhirat. Di antara beberapa remaja ada yang bertambah rajin beribadah, apabila merasakan bersalah (dosa). Semakin besar rasa dosanya, semakin banyak ibadahnya dan sebaliknya, apabila rasa dosa itu kurang, maka ibadahnya juga menurun. Ibadah bagi remaja seolah-olah untuk menentramkan batin yang gelisah, karena merasa bersalah dan merasa kalah menghadapi dorongandorongan yang sedang mengikuti arus darah mudanya dalam pergaulan (Daradjat, 1996:84). Agama juga merupakan sarana pembinaan moral agar mendapat kesejahteraan dan kedamaian dalam hidup dan dapat dipergunakan untuk mengendalikan diri dari keangkuhan, kesombongan, perilaku asosial dan segala macam bentuk kejahatan lainnya.

Agama Islam mengajarkan berbagai macam puasa, tetapi tak ada satupun puasa yang dikaitkan dengan kedukaan. Bahkan sebaliknya, puasa yang wajib dilakukan umat Islam adalah puasa penuh selama Ramadhan (Rahim, 1998: 29). 
Hakikat puasa dalam pengertian Muhammad Abduh dan Muhammad Rasyid Ridha dalam tafsir "Al-Manar" (Asghary, 1994, hal: 82) yaitu puasa bukan hanya sekedar menahan diri dari makan, minum dan bersenggama; melainkan juga mampu menahan diri dari perkataan kotor dan sifat keji. Jika hal itu tidak ditinggalkan, walaupun seseorang itu telah menahan diri dari makan, minum, dan bersenggama maka Allah SWT tidak akan memberikan nilai pahala kepadanya. Hal-hal yang dilakukan saat puasa membuat diri seseorang menjadi lebih bisa memahami arti kehidupan. Misalnya, menahan lapar ini merupakan proses pembelajaran untuk lebih peduli pada kaum dhuafa. Menahan amarah juga akan melatih kesabaran. Melalui kesabaran itulah dapat melihat persoalan-persoalan yang dihadapi dengan pikiran yang jernih (Wawasan, 30 September 2006 : 9).

Pengertian puasa menurut ilmu bahasa adalah menahan diri dari sesuatu. Dalam pengertian syara' (aturan agama Islam) diartikan sebagai suatu bentuk ibadah dengan cara menahan diri dari makan, minum, berhubungan seks, dan lain sebagainya dari sejak terbit fajar sampai terbenam matahari dengan niat untuk mendapatkan ridha Allah SWT dan dalam usaha untuk mempersiapkan menjadi insan yang takwa (Al Zuhaily, 2004 : 84).

Perjuangan untuk melawan hawa nafsu di bulan Ramadhan sama halnya dengan berlaga di medan perang melawan musuhal: Ada beberapa tipe nafsu yang dapat merusak, mengubah bahkan menghancurkan jalannya ibadah puasa ramadhan tetapi salah satunya yang harus diwaspadai adalah nafsu amarahal: Terkait dengan melawan hawa nafsu, maka ada beberapa bagian tubuh yang harus dijaga yaitu mata, telinga, mulut, hati dan kemaluan. Hal lain yang perlu diingat bahwa dasar moral adalah pengenalan yang benar akan hakikat Allah SWT mengenai hakikat kesucian, keadilan dan kemahakuasaan Allahal: Sehingga harus selalu beriman kepada Allah SWT dan dapat memotivasi diri sendiri untuk dapat menjalankan ibadah puasa dengan benar (Nursanti, 2006: 36). 
Hal terpenting yang perlu ditumbuhkan pada remaja sebelum berpuasa adalah motivasi yang timbul karena adanya rasa bangga akan kemampuan dirinya untuk menjalankan ibadah puasa. Memotivasi para remaja untuk berpuasa tidak bisa dilakukan dengan cara paksa melainkan dengan memberikan perhatian ekstra. Motivasi merupakan suatu tenaga atau faktor yang terdapat dalam diri manusia yang menimbulkan, mengarahkan dan mengorganisasikan tingkah laku seseorang. Faktor yang mempengaruhi motivasi seseorang antara lain yaitu faktor eksternal dan faktor internal. Faktor eksternal merupakan faktor yang berasal dari luar individu, meliputi dukungan sosial, lingkungan dan orang tua. Faktor internal merupakan faktor yang berasal dari dalam diri individu, yang mengarahkan pada tingkah laku tertentu dan merupakan kepercayaan diri yang timbul karena tekad dan perasaan untuk mampu melaksanakan segala yang dibutuhkan dalam hidup (Rahim, 2006: 85).

Tujuan utama memotivasi dalam berpuasa adalah agar dalam diri remaja tumbuh kecintaan terhadap ibadah puasa. Cara memotivasinya dapat dilakukan dengan cara berdialog mengenai puasa, memberikan reward berupa hadiah uang atau sesuatu yang diinginkan, dalam hal ini cenderung untuk memperlemah dirinya untuk menjalankan puasa tapi bukan berarti tidak boleh diterapkan sama sekali melainkan apabila motivasinya sangat lemah, orang tua dapat menerapkan cara ini sebagai motivator sementara. Dengan catatan jangan sampai hadiah itu dijadikan tujuan utama dan bukan lagi sebagai motivator sementara. Cara selanjutnya untuk memotivasi adalah dengan memberikan pujian sehingga akan termotivasi dan merasa dihargai karena dengan pujian bisa menjadi hadiah istimewa.

Motivasi yang kuat untuk berpuasa menyebabkan fisik seseorang siap untuk menghadapi sesuatu yang diakibatkan oleh puasa tersebut. Diketahui dari penelitian oleh para ahli kesehatan dan para dokter bahwa kadar asam lambung orang yang niat berpuasa lebih rendah dari pada orang yang kelaparan. Hal ini

Ilmu Dakwah: Academic Journal for Homiletic Studies Vol. 6 No. 2 Desember 2012253 
karena niat atau motivasi puasa yang menyebabkan penekanan pusat lapar di otak sehingga siap untuk menahan lapar sampai waktu buka. Dengan menjalankan ibadah puasa dapat menghindarkan diri dari penyakit-penyakit yang berarti fisik seseorang terpelihara dan sehat. Demikian pula dengan jiwa dan rohani, karena berpuasa rohaninya bersih dan akan timbul perasaan iba kepada orang lain yang lebih menderita sehingga akan dapat mengekang hawa nafsunya dan mampu mendisiplinkan diri. Ini semua adalah sebagian dari rahasia "la'allakum tattaqûn" (agar mereka bertakwa), dan demikianlah hikmah yang diperoleh bila berpuasa dengan baik dan benar menurut tuntunan Nabi Muhammad SAW.

Puasa menjadi sumber penumbuh kekuatan cita-cita, kehendak dan kemauan. Puasa sebagai sumber yang memancarkan kekuatan beragama dan penambahan kekuatan sinar iman di dalam batin. Selain dari itu, puasa menjadi sumber pokok kekuatan dan kesehatan baik jasmani maupun rohaniah serta menambah lemah lembut dan kehalusan budi pekerti dan akhlak mulia (Zainuddin, 1992: 46).

Seseorang yang mempunyai motivasi berpuasa yang tinggi maka ibadah puasanya tinggi atau baik sehingga menyebabkan moralitasnya juga tinggi. Misalnya pada saat mengerjakan puasa walau dalam kondisi panas, merasakan haus dan lapar tetapi dirinya tidak tergoda untuk membatalkan puasanya karena telah mempunyai motivasi berpuasa yang tinggi. Ibadah puasa tidak hanya dengan menahan diri dari makan dan minum tetapi harus diikuti dengan ibadah yang lain, misalnya lebih tekun mengerjakan sholat lima waktu, sholat sunah, dan tidak lupa untuk selalu bersedekah: 


\section{B. Landasan Teori}

\section{Moralitas Remaja}

Panuju dan Umami (1999: 135) yang mengatakan bahwa moralitas remaja adalah akhlak, tingkah laku, tindakan atau ideide yang dijalankan oleh remaja dengan penilaian baik atau buruk. Sesungguhnya perkembangan kesadaran moral pada remaja menyebabkan mereka untuk menambah perhatiannya terhadap ajaran-ajaran agamanya dan kitab sucinya. Misalnya, remaja akan lebih tekun sembahyang dan berdoa dengan sungguh-sungguh karena hal itu merupakan permohonan akan pertolongan kepada Allah dalam menghadapi hidupnya dan memohon Ridho-Nya (Daradjat, 1991: 50).

Moral dan religi merupakan bagian yang cukup penting dalam jiwa remaja karena dapat mengendalikan tingkah laku sehingga tidak akan melakukan hal-hal yang bertentangan dan merugikan kehendak atau pandangan masyarakat. Di sisi lain tiadanya moral dan religi seringkali menjadi masalah sebagai faktor penyebab meningkatnya kenakalan remaja (Sarwono, 2003: 91).

Berdasarkan uraian di atas maka dapat disimpulkan bahwa moralitas remaja adalah tingkat ketaatan dan kepatuhan seorang individu yang mengatur perilakunya berdasarkan budaya tertentu. Individu yang dimaksud adalah individu yang sedang berada pada masa peralihan atau masa transisi dari masa kanakkanak ke masa dewasa yang ditandai dengan timbulnya tandatanda pubertas dan kematangan seksual, perubahan dalam ciri berfikir dan bertindak. Periode ini terjadi pada masa remaja yang mempunyai batasan usia antara usia 12 sampai 21 tahun. Subyek yang akan digunakan dalam penelitian ini adalah masa remaja akhir.

Gunarsa (1995: 39) menyatakan bahwa ada beberapa faktor yang mempengaruhi perkembangan moral, yaitu: Lingkungan rumah, Lingkungan Sekolah, Lingkungan teman-teman, Segi 
keagamaan, Aktivitas rekreasi. Sarwono (1989: 82) menambahkan satu faktor lagi yang dapat mempengaruhi moralitas remaja yaitu intelegensi. Kemampuan individu yang mengambil keputusan tentang moral berhubungan dengan perkembangan kognitif. Setiap orang mempunyai sistem pengaturan diri serta kognisinya yang berkembang sesuai dengan perkembangan aspek-aspek kognitifnya. Aspek-aspek itu antara lain kematangan, pengalaman, transisi, sosial dan keseimbangan.

Berdasarkan teori di atas maka dapat disimpulkan bahwa faktor-faktor yang dapat mempengaruhi perkembangan moral pada remaja adalah lingkungan rumah, lingkungan sekolah, lingkungan teman-teman, segi keagamaan, aktivitas rekreasi dan intelegensi.

Daradjat (1988: 39) mengemukakan beberapa aspek dalam moralitas remaja, yaitu:

a. Sikap baik, yakni kecenderungan bertingkah laku yang didasari oleh hasrat, motivasi, pengalaman, dan kehidupan alam perasaan, kesabaran, tabah, keramahtamahan dan adil, senang berbuat kebaikan terhadap sesamanya dan jujur dalam bersikap.

b. Sifat ke-Tuhanan, yang meliputi ketaatan, kepatuhan, keikhlasan, kasih sayang, pemaaf dan bijaksana. Sifat keTuhanan ini dapat dikatakan bahwa pemikiran moral datangnya bersamaan dengan munculnya sifat akhlak bagi Tuhan, menambah suburnya rasa ke-Tuhanan dan adanya sifat-sifat baik.

c. Norma, adalah aturan standar, ukuran sesuatu yang sudah pasti, yang dapat dipakai untuk membandingkan sesuatu berdasarkan hakikatnya, besar kecilnya, ukurannya dan semua itu bisa mengukur kebaikan dan keburukan suatu perbuatan.

Hadiwardoyo (1990: 21) berpendapat bahwa aspek moralitas adalah: kejujuran, kesabaran, kesetiaan, keterbukaan, 
keberanian, keadilan,kebijaksanaan, kepercayaan, penuh harapan, kasih pada sesama, kerendahan hati, ketekunan kerja.

Berdasarkan uraian diatas maka dapat disimpulkan bahwa aspek-aspek moralitas remaja yang digunakan adalah sikap baik, kasih sayang, kejujuran dan keadilan. Pertimbangan pemilihan aspek-aspek tersebut karena ada kemiripan dan mempunyai arti yang sama mengenai aspek moralitas yang diungkapkan oleh Daradjat dan Hadiwardoyo, sehingga penulis hanya mengambil beberapa aspek yang sesuai dengan definisi dari moralitas remaja.

\section{Motivasi Berpuasa Ramadhan}

Hal terpenting yang perlu ditumbuhkan pada remaja sebelum puasa adalah motivasi intrinsik. Motivasi intrinsik adalah motivasi yang timbul karena adanya rasa bangga akan kemampuan diri. Rasa bangga terhadap kemampuan diri inilah yang disebut penghargaan intrinsik (Adhim, 2006 : 24).

Bagi setiap muslim, puasa sebagaimana halnya dengan rukun Islam yang lain harus dilaksanakan dengan taat, sesuai dengan hakikat perintah Allah SWT. Puasa mendidik seseorang untuk bersikap jujur dan merasa diawasi oleh Allah SWT, baik dalam kesendirian maupun dalam keramaian karena pada saat itulah tidak seorangpun yang mengawasi orang yang berpuasa selain Allah SWT. Dengan demikian pada situasi tertentu seorang remaja harus diberikan motivasi dan penghargaan untuk mengantisipasi saat-saat kritis melalui cara memberikan kegiatan dan kreativitas yang paling menarik bagi anak (Asghary, 2000 : 89).

Berdasarkan penjelasan di atas maka dapat disimpulkan bahwa motivasi berpuasa ramadhan adalah suatu dorongan yang mempengaruhi tingkah laku seseorang untuk menjalankan ibadah puasa di bulan Ramadhan dengan mentaati apa yang diperintahkan oleh Allah SWT dengan menahan diri dari segala sesuatu yang membatalkan puasa dari terbit fajar sampai terbenamnya matahari disertai niat karena Allah SWT dengan syarat dan rukun tertentu.

Ilmu Dakwah: Academic Journal for Homiletic Studies Vol. 6 No. 2 Desember 2012257 
Purwanto (1998: 72) menyatakan bahwa aspek-aspek dalam motivasi adalah sebagai berikut:

a. Menggerakkan. Berarti menimbulkan kekuatan pada individu dalam memimpin seseorang untuk bertindak dengan cara tertentu. Maksud dari menggerakkan di sini yaitu memberikan materi dan ajaran mengenai motivasi berpuasa berupa tujuan berpuasa, kewajiban berpuasa dan hikmah berpuasa.

b. Mengarahkan. Motivasi menyediakan suatu orientasi tujuan tertentu. Dalam hal ini tingkah laku individu diarahkan terhadap sesuatu. Maksud dari mengarahkan di sini yaitu individu diberikan motivasi agar dapat menjalankan puasa seperti yang telah diperintahkan dalam agamanya.

c. Menopang. Untuk menjaga tingkah laku, peran lingkungan sekitar harus dapat menguatkan intensitas dan arah, dorongan-dorongan, kekuatan individu. Maksud dari menopang di sini yaitu dalam proses pemberian motivasi ini lingkungan turut serta aktif dalam proses penyampaiannya.

Siagian (1995: 138) mengatakan bahwa aspek motivasi mengandung komponen utama yaitu:

a. Kebutuhan. Kebutuhan timbul dalam diri seseorang apabila ia merasa adanya kekurangan dalam dirinya. Maksud dari kebutuhan di sini yaitu remaja akan tekun menjalankan ibadah puasa Ramadhan dikarenakan sebelumnya tidak pernah menjalankan puasa karena belum begitu mengerti makna dari puasa tersebut.

b. Dorongan. Dorongan timbul dari usaha untuk mengatasi ketidakseimbangan. Dorongan merupakan usaha pemenuhan kekurangan secara terarahal: Dorongan berorientasi pada tindakan tertentu yang secara sadar dilakukan seseorang. Maksud dari dorongan di sini yaitu 
dorongan yang diberikan oleh keluarga untuk para remaja agar dapat menjalankan ibadah puasa dengan benar.

c. Tujuan. Tujuan adalah segala sesuatu yang menghilangkan kebutuhan dan mengurangi dorongan. Maksud dari tujuan di sini yaitu tujuan dari para remaja menjalankan ibadah puasa adalah untuk mendapatkan ampunan dan ridho dari Allah SWT.

Berdasarkan uraian beberapa aspek yang telah dikemukakan para tokoh maka dapat disimpulkan bahwa aspek-aspek motivasi berpuasa ramadhan adalah menggerakkan, mengarahkan dan tujuan. Pertimbangan pemilihan aspek tersebut karena dari beberapa tokoh menyebutkan aspek-aspek motivasi yang mempunyai kemiripan dan kesamaan arti sehingga hanya mengambil aspek-aspek yang sesuai dengan definisi dari motivasi berpuasa ramadhan.

\section{Metode Penelitian}

Metode pengumpulan data dalam penelitian ini menggunakan dua skala, yaitu skala motivasi berpuasa ramadhan dan skala moralitas remaja yang difokuskan pada 115 siswa kelas VIII SMP Muhammadiyah 3 Bandung yang diambil melalui teknik area sampling. Kemudian, skala motivasi berpuasa ramadhan disusun berdasarkan aspek-aspek motivasi berpuasa ramadhan yaitu mengerakkan, mengarahkan, dan tujuan. Skala moralitas remaja disusun berdasarkan aspek-aspek moralitas remaja yaitu sikap baik, kasih sayang, kejujuran, keadilan. Sebelum skala digunakan dalam penelitian, dilakukan uji validitas dan uji reliabilitas skala. Skala motivasi berpuasa ramadhan dari 48 item terdapat 37 valid dan 11 item gugur. Koefisien validitas skala motivasi berpuasa ramadhan berkisar antara 0,3095 sampai dengan 0,5181. Pengujian terhadap reliabilitas skala motivasi berpuasa ramadhan dilakukan berdasarkan pada 37 item yang

Ilmu Dakwah: Academic Journal for Homiletic Studies Vol. 6 No. 2 Desember 2012259 
valid dengan menggunakan teknik Alpha. Berdasarkan uji reliabilitas terhadap skala motivasi berpuasa ramadhan diperoleh koefisien Alpha sebesar 0,8574, sehingga hasil uji coba motivasi berpuasa ramadhan dikatakan reliabel. Skala moralitas remaja dari 56 item terdapat 42 item valid dan 14 item gugur. Koefisien validitas skala moralitas remaja berkisar antara 0,3027 sampai dengan 0,6539. Pengujian terhadap reliabilitas skala moralitas remaja dilakukan berdasarkan 42 item yang valid dengan menggunakan teknik alpha. Berdasarkan uji reliabilitas terhadap skala moralitas remaja diperoleh koefisien reliabilitas Alpha sebesar 0,8958, sehingga hasil uji coba moralitas remaja dikatakan reliabel.

Analisis data dalam penelitian ini menggunakan teknik korelasi Product Moment, karena penelitian ini ingin mengetahui hubungan antara skala motivasi berpuasa ramadhan dengan skala moralitas remaja.

\section{Pembahasan}

Berdasarkan hasil penelitian yang telah dilakukan menunjukkan bahwa ada hubungan positif dan sangat signifikan antara motivasi berpuasa ramadhan dengan moralitas remaja. Hal ini dapat dilihat dari $r_{x y}$ sebesar 0,546 dengan $p<0,01$, sehingga semakin tinggi motivasi berpuasa ramadhan maka semakin tinggi moralitas remaja, dan sebaliknya, semakin rendah motivasi berpuasa ramadhan maka semakin rendah moralitas remaja.

Dengan demikian, hipotesis dalam penelitian ini terbukti, yaitu ada hubungan positif antara motivasi berpuasa ramadhan dengan moralitas remaja. Hasil yang diperoleh ini sesuai dengan pendapat Nursanti (2006, hal: 36) yang menyatakan bahwa hal lain yang perlu diingat bahwa dasar moral kita adalah pengenalan yang benar akan hakikat Allah SWT mengenai hakikat kesucian, keadilan dan kemahakuasaan Allahal: Oleh karena itu kita juga harus selalu beriman kepada Allah SWT dan dapat memotivasi 
diri kita sendiri untuk dapat menjalankan ibadah puasa dengan benar. Tujuan utama memotivasi dalam berpuasa adalah agar dalam diri kita tumbuh kecintaan terhadap ibadah puasa. Cara memotivasinya dapat dilakukan dengan cara berdialog mengenai puasa, memberikan reward berupa hadiah uang atau sesuatu yang diinginkan dan memotivasi dengan memberikan pujian sehingga akan termotivasi dan merasa dihargai karena dengan pujian bisa menjadi hadiah istimewa.

Puasa merupakan madrasah moralitas yang besar dan dapat dijadikan sarana latihan untuk menempa berbagai macam sifat terpuji. Puasa adalah jihad melawan hawa nafsu, manangkal godaan-godaan dan rayuan-rayuan syetan yang terkadang terlintas dalam pikiran. Puasa bisa membiasakan orang bersikap sabar terhadap hal-hal yang diharamkan, penderitaan, dan kesulitan yang kadangkala muncul dihadapannya. Misalnya, pada saat dia melihat hidangan makanan lezat dihadapannya, yang baunya menyeruak sampai ke perut, atau dia melihat air tawar yang sejuk menari-nari dihadapan matanya, maka pada saat itu pula dia harus menahan diri dari semuanya dan menunggu sampai waktu yang diizinkan (Al Zuhayly, 2004 : 87).

Berdasarkan mean empirik dari motivasi berpuasa ramadhan dihasilkan Mep $=92$, sedangkan $M H p=37$ dengan $\mathrm{R}=$ 111 dan $S d=18,5$. Mean empirik yang dihasilkan dari moralitas remaja adalah Mep $=112$, sedangkan $\mathrm{MHp}=42$ dengan $\mathrm{R}=126$ dan $\mathrm{Sd}=21$. Hal ini menunjukkan bahwa mean empirik lebih besar daripada mean hipotetik, sekaligus mengkategorisasikan motivasi berpuasa ramadhan dan moralitas remaja masuk ke dalam golongan yang tinggi. Jumlah siswa yang terdapat dalam kategorisasi tinggi pada skala motivasi berpuasa ramadhan sebanyak 86 siswa dan jumlah siswa yang terdapat dalam kategorisasi tinggi pada skala moralitas remaja sebanyak 93 siswa. Hal ini didukung oleh wawancara informal yang dilakukan dengan para siswa yang memiliki motivasi dalam dirinya untuk dapat mengerjakan puasa dengan benar, sehingga mereka akan

Ilmu Dakwah: Academic Journal for Homiletic Studies Vol. 6 No. 2 Desember 2012261 
memperoleh sesuatu dari usahanya tersebut. Beberapa siswa yang belum dapat sepenuhnya memotivasi dirinya untuk dapat mengerjakan puasa ramadhan tampak kesulitan sehingga mereka membutuhkan dukungan dan dorongan dari teman-temannya dan dapat juga mengikuti kegiatan keagamaan yang diadakan di sekolah selama bulan ramadhan.

Seorang remaja yang memperhatikan dan mengerti tentang apa hikmah yang didapatkan dengan menjalankan ibadah puasa maka dia dapat menimbang-nimbang dan akhirnya dapat mengambil keputusan sendiri mengenai apa yang dianggap baik dan buruk. Apalagi seorang remaja yang berada dalam masa transisi membuat remaja dihadapkan pada berbagai kontradiksi. Masa remaja merupakan peralihan dari masa kanak-kanak ke masa dewasa yang lebih matang dan mampu berdiri sendiri, sehingga remaja mampu memikirkan nilai dan standar moral yang muncul dari agama dan lingkungan sosial (Mussen, 1989 : 542). Jika remaja mempunyai landasan agama yang kuat maka remaja mempunyai motivasi untuk menjalankan ibadah puasa sehingga mereka dapat meningkatkan moralnya.

Moral dan religi merupakan bagian yang cukup penting dalam jiwa remaja karena dapat mengendalikan tingkah laku sehingga tidak akan melakukan hal-hal yang bertentangan dan merugikan kehendak atau pandangan masyarakat. Di sisi lain tiadanya moral dan religi seringkali diruding sebagai faktor penyebab meningkatnya kenakalan remaja (Sarwono, 2003 : 91).

Panuju dan Umami (1999: 135) mengatakan bahwa moralitas remaja adalah akhlak, tingkah laku, tindakan atau ideide yang dijalankan oleh remaja dengan penilaian baik atau buruk. Perkembangan kesadaran moral pada remaja sesungguhnya menyebabkan mereka untuk menambah perhatiannya terhadap ajaran-ajaran agamanya dan kitab sucinya. Misalnya, remaja akan lebih tekun sembahyang dan berdoa dengan sungguh-sungguh karena hal itu merupakan permohonan akan pertolongan kepada 
Allah dalam menghadapi hidupnya dan memohon Ridho-Nya (Daradjat, 1996 : 50).

Pendidikan agama yang diperoleh dalam diri remaja juga harus diimbangi dengan moral agama yang merupakan usaha untuk memberikan kepada remaja suatu pedoman dan aturanaturan dalam kehidupan yang berdasarkan nilai-nilai agama agar remaja dapat mematuhi dan mengamalkannya dalam berinterkasi dengan lingkungan juga dapat digunakan sebagai bekal kehidupan di akhirat. Agama juga merupakan sarana pembinaan moral agar mendapat kesejahteraan dan kedamaian dalam hidup dan dapat dipergunakan untuk mengendalikan diri dari keangkuhan, kesombongan, perilaku asosial dan segala macam bentuk kejahatan lainnya.

Dari pembahasan di atas menunjukkan bahwa remaja memiliki motivasi berpuasa ramadhan dan moralitas yang tinggi karena lebih memfokuskan pada kualitas individunya yang lebih dirasakan dan mempengaruhi mereka.

\section{E. Penutup}

Berdasarkan hasil analisis data dan pembahasan atas hasil penelitian, maka dapat disimpulkan sebagai berikut :

1. Terdapat hubungan positif yang sangat signifikan antara motivasi berpuasa ramadhan dengan moralitas remaja. Semakin tinggi motivasi berpuasa ramadhan maka moralitas remaja juga semakin tinggi, sebaliknya semakin rendah motivasi berpuasa ramadhan maka moralitas remaja juga semakin rendahal:

2. Besarnya pengaruh variabel motivasi berpuasa ramadhan terhadap variabel moralitas remaja sebesar $29,8 \%$, sedangkan sisanya sebesar 70,2\% merupakan sumbangan dari faktor-faktor lain yang mempengaruhi moralitas remaja antara lain lingkungan rumah,

Ilmu Dakwah: Academic Journal for Homiletic Studies Vol. 6 No. 2 Desember 2012263 
lingkungan sekolah, lingkungan teman-teman, segi keamanan dan aktivitas rekreasi.[] 


\section{DAFTAR PUSTAKA}

Ali, M. D. 2002. Pendidikan Agama Islam. Jakarta: PT. Raja Grafindo Persada.

Al-Zuhayly, W. 2004. Puasa dan I'tikaf. Bandung: Rosdakarya.

Asghary, B.I. 1994. Solusi Al Qur'an. Jakarta: Rineka Cipta.

Daradjat, Z. 1991. Kesehatan Mental. Jakarta: Gunung Agung.

Duksa, R.,Whelan, M. 1984. Perkembangan Moral. Alih Bahasa: Dwija Admadja. Yogyakarta: Kanisius.

Gazalba, S. 1985. Asas Agama Islam. Jakarta: PT. Bulan Bintang.

Gunarsa, D. S. 1995. Psikologi Perkembangan Anak dan Remaja. Jakarta: BPK Gunung Mulia.

Hadiwardoyo, A.C.P. 1990. Moral dan Masalahnya. Yogyakarta: Kanisius.

Panuju, P., Umami, I. 1999. Psikologi Remaja. Yogyakarta: PT. Tiara Wacana.

Purwanto, M. N. 1998. Psikologi Pendidikan. Bandung: PT. Remaja Rosda Karya.

Rahim, S. 1998. Puasa Siapa yang Boleh Meninggalkannya. Jakarta: Antar Kota.

Rahim, M.A. 2006. Sepuluh Tehnik Membangun Motivasi Optimalisasi Ramadhan. Jakarta: Rineka Cipta.

Republika. 2006. Shaum yang Diterima. 3 Oktober 2006

Salim, A.M. 1991. Bersama Rasulullah Di Bulan Ramadhan. Surabaya: Pustaka Progressif.

Sarwono, S.W. 2003. Psikologi Remaja. Jakarta: PT. Raja Grafindo Persada.

Zainuddin. 1992. Pahala dalam Islam. Jakarta: Rineka Cipta.

Ilmu Dakwah: Academic Journal for Homiletic Studies Vol. 6 No. 2 Desember 2012265 